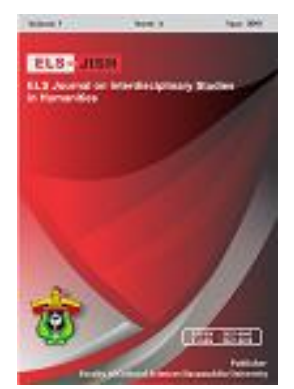

ELS-JISH

ELS Journal on Interdisciplinary Studies on Humanities

Volume 2 Issue 2, 2019

ISSN (print) : 2621-0843

ISSN (online) : 2621-0835

Homepage : http://journal.unhas.ac.id/index.php/jish

\title{
Geographic Innovation of Bugis Language and Makassar Language (Indonesian Geographic Variation)
}

\author{
Laeli Qadrianti ${ }^{1}$, Kasri Riswadi² \\ 1'laeliqadrianti@gmail.com
}

\begin{abstract}
This paper aims to describe the geographical variation of the Makassar language and the Bugis language. Language variations are due to the geographical conditions of the speaking community. Geographical differences in society separate people into groups consisting of ethnic groups. The diversity of ethnic groups has resulted in cultural differences including language and variations. Social factors, time factors, and individual language users give rise to variations in language. This research method uses descriptive qualitative, data collection is done by referring to the method of free involvement, recording, and recording. Data obtained through referral methods, recording techniques, and notes are then analyzed by classifying and grouping. In grouping steps are used, namely 1) Data Identification, 2) Data Classification, 3) Data Analysis. The results of this study found that there were words in the Makassar language and Bugis language that experienced full lexical innovation and partial lexical innovation.
\end{abstract}

Keywords: Variation, Geography, Bugis Language

How to cite: Qadrianti, L., \& Riswadi, K. (2019). Geographic Innovation of Bugis Language and Makassar Language (Indonesian Geographic Variation). ELS Journal on Interdisciplinary Studies in Humanities, 2 (2), 206-215.

\section{Introduction}

Language variation or variety of languages is the use of language according to the wearer, which varies according to the topic being discussed, according to the speaker relationship, friend to talk, and the person discussed and according to the medium of conversation (KBBI, 2003: 920). A language has a system and subsystem that is understood by the speakers of the language. However, because speakers of the language, even though they are in a speech society, are not a collection of homogeneous humans, concrete forms of language, called paroles, are not uniform or varied. The occurrence of diversity or variance of this language is not only caused by the speakers who are not homogeneous, but also the activities of social interaction that they do are very diverse (Chaer \& Agustina, 2004: 61).

Every language has different variations. Language variation is a set of human speech patterns that suffice sounds, words, and grammatical features that can be

${ }^{1,}$ STMIK Bina Adinata, Indonesia 
uniquely associated with external factors, such as geography and social factors (Wardhaugh, 1986: 22). Language variations according to C.A. Ferguson and J.D. Gumperz in Allen (1973: 92) says "a variety of large repertory of elements and their arragements or processes with broad enough semantic scope to function in all normal contexts of communication ". From this definition it can be seen that there are the same language patterns, the patterns of language can be analyzed descriptively, patterns that are limited by that meaning are used by the speaker to communicate. According to Kridalaksana variation is a manifestation of various conditional and unconditional manifestations of one unit, concepts that include variables and variants.

According to Ayatrohaedi (1983: 3), each language is used in a particular area, and gradually a different element of language is formed, such as in pronunciation, grammar, and meaning, and each variety uses one particular form. according to dialects (Guiraud 1970 in Ayatrohaedi (1983: 3-5) and Wahya (2015: 9) are divided into five types, the five types of differences are:

a. Phonetic difference. That difference is in the field of phonology such as careme and cereme

b. Semantic differences, as well as synonymy of different names for the same symbol such as turi and turuy

c. Onomasiological differences that show different names based on one concept given in several different places.

d. Semasiological differences which are the opposite of onomasiological differences, namely giving the same name to several different concepts.

e. Morphological differences which are limited by the existence of the grammar system in question, different frequency of morphemes, related uses, phonetic form, taste, and a number of other factors.

All of these things support the understanding of the birth of an innovation. Therefore, in language innovation, it must be distinguished by two stages, namely the creation of an individual and acceptance in a language society which is a social reality.

Renewal or innovation according to Kridalaksana (1993: 84) is a change in sound, form, or meaning that results in the creation of a new word. According to Wahya (2006: 52) innovation covers two sides, namely processes and results. As a process of innovation is the creation of new forms or meanings as a result of changes in their original form or meaning. As a result, innovation is a new form and meaning that appears in the area of use of the isolek concerned. Language innovation can occur from inside and outside. Innovation from within (Internal innovation) is related to the renewal of the language system due to the potential of the language itself while external innovation (external innovation) is related to the renewal of language systems due to the influence of other languages.

Makassar Language is one of the Austronesian languages in the MalayPolynesian branch spoken by the Makassar tribe in the southern part of South Sulawesi, spread in Makassar city, Gowa regency, Takalar district, Jeneponto district, Bantaeng district, Selayar district, part of Bulukumba district, part of Maros 
district, and Pangkep district in part. The Makassar language consists of several dialects, including Makassar Lakiung, Turatea Je'neponto, Bantaeng, Konjo and Selayar.

Bugis language is also one of the Austronesian language groups used by ethnic Bugis in South Sulawesi, which is spread in parts of Maros Regency, Pangkep Regency, Barru Regency, Parepare City, Pinrang Regency, part of Enrekang Regency, part of Majene Regency, Luwu Regency, Regency Sidenreng Rappang, Soppeng Regency, Wajo Regency, Bone Regency, Sinjai Regency, part of Bulukumba Regency, and part of Bantaeng Regency.

Bugis language consists of several dialects. Like the Pinrang dialect which is similar to the Sidrap dialect, the Bone dialect (which differs between North and South Bone), the Soppeng dialect, the Wajo dialect (also different between north and south Wajo, and east and west), Barru dialect, Sinjai dialect, and so on. . This diversity is what makes Bugis language interesting to study.

Makassar language and Bugis language as described earlier are languages found in South Sulawesi. The Makassar language is used in the southern part of South Sulawesi and the language of Bugis is mostly used in South Sulawesi for intermediates in North Sumatra. The two languages that face the same province still have many similarities even though the presentation of cognates is not so great. Both of these topics are interesting to be studied further, especially on innovations that occur in the Makassar language (bM) which are viewed from Bugis language (bB) even though there has been no research that describes the region which gave birth to a similar vocabulary in the two regions in question.

\section{Methodology}

This research is classified as qualitative descriptive research. Jufri (2007: 12) states that the characteristics of qualitative research are: (1) having a natural background as direct data, (2) being descriptive, (3) emphasizing processes rather than results, (4) tend to analyze data inductively, and (5) meaning is essential.

Qualitative descriptive research, namely explaining data in accordance with the actual data state. According to Moleong (2009), qualitative methods as research procedures produce descriptive data in the form of written or oral words from the people observed.

Data collection is done by referring to the method of free engagement, recording, and recording. The method of referring to involvement is proficient, the researcher only acts as a language observer to the informants.

Data obtained through referral methods, recording techniques, and notes are then analyzed by classifying and grouping. In the grouping steps are used, namely 1) Data Identification. All utterances are Makassarese and Bugis. 2) Data Classification. The data is then classified based on the forms of mixed code, code switching, and interference, 3) Data Analysis. Data are analyzed contextually based on speech events (Mutmainah, 2018)

\section{Discussion}

In the discussion the data and classification of data analysis is described in relation to the Makassar language (bM) and Bugis language (bB). The data 
described is the Swadesh vocabulary that has been translated into both languages. For more details, see the following table.

Table 1. Vocabulary of Makassarese and Buginese Language

\begin{tabular}{|c|c|c|c|}
\hline No. & English & Makassarese & Buginese \\
\hline 1. & 1 & Nakke & iya' \\
\hline 2. & You & Ikau & idi', iko \\
\hline 3. & $\mathrm{He}$ & la & Alena \\
\hline 4. & We/Us & Katte & Idi' \\
\hline 5. & White & Kebo & Mapute \\
\hline 6. & They & Anjongaseng & Yamaneng \\
\hline 7. & This & Anne & Yae \\
\hline 8. & That & Antu & Yaro \\
\hline 9. & Bitter & Pai' & Mapai \\
\hline 10. & Stone & Batu & Batu \\
\hline 11. & Who & Inai & Niga \\
\hline 12. & What & Apa & Aga \\
\hline 13. & Where & Kemae & Kega \\
\hline 14. & When & Sikaranna & Uppanna \\
\hline 15. & Chicken & Jangang & Manu \\
\hline 16. & Not & Teai & Tania \\
\hline 17. & All & lyangaseng & Maneng \\
\hline 18. & Many & Loe & Mega \\
\hline 19. & The sea & Tamparang & Tasi \\
\hline 20. & A little & Si'di & Ce'de \\
\hline 21. & Pencil & Potolo & Potolo \\
\hline 22. & One & Se're & Se'di \\
\hline 23. & Two & Rua & Duwa \\
\hline 24. & Three & Tallu & Tellu \\
\hline 25. & Four & Appa & Eppa \\
\hline 26. & Five & Lima & Lima \\
\hline 27. & Big & Lompo & Maloppo \\
\hline 28. & Long & La'bu & Malampe \\
\hline 29. & Baring & Monrang & Leu \\
\hline 30. & Thick & Kapala' & Maumpe' \\
\hline 31. & Weight & Battala' & Matane' \\
\hline 32. & Water & Je'ne & Wae \\
\hline 33. & Spoon & Sondok & Sinru \\
\hline 34. & Narrow & Seppang & Macipi' \\
\hline 35. & Thin & Tipisi & Manipi' \\
\hline 36. & Women & Baine & Makkunrai \\
\hline 37. & Man & Bura'ne & Urane \\
\hline 38. & Human & Rupatau & Tau \\
\hline 39. & Child & Ana' & Ana' \\
\hline 40. & Wife & Baine & Bene \\
\hline 41. & Husband & Bura'ne & Lakkai \\
\hline
\end{tabular}


ISSN: (E) 2621-0835, (P) 2621-0843

\begin{tabular}{|c|c|c|c|}
\hline 42. & Motehr & Ammak & Indo \\
\hline 43. & Father & Angge' & Ambo' \\
\hline 44. & Fish & Juku' & Bale \\
\hline 45. & Bird & Jangang-Jangang & Dongi' \\
\hline 46. & Seven & Tuju & Pitu \\
\hline 47. & Lice & Kutu & Utu \\
\hline 48. & Snake & Ulara' & Ula' \\
\hline 49. & Line & Garisi & Garisi \\
\hline 50. & Bag & Tasi & Tase \\
\hline 51. & Forest & Romang & Ale' \\
\hline 52. & Fruit & Bua & Bua \\
\hline 53. & Leaf & Raung & Raun \\
\hline 54. & Root & Aka' & Ure' \\
\hline 55. & Skin & Bukkuleng & Uli' \\
\hline 56. & Clothes & Baju & Waju \\
\hline 57. & Spoon & Sondok & Sinru \\
\hline 67. & Flower & Bunga & Bunga \\
\hline 68. & Rope & Passikko' & Tulu' \\
\hline 69. & Meat & Dageng & Juku' \\
\hline 70. & Blood & Cera' & Cera' \\
\hline 71. & Bone & Buku & Kabuttu \\
\hline 72. & Fat & Janna & Lappe \\
\hline 73. & Egg & Bayao & Tello \\
\hline 74. & Horn & Tanru' & Tanru' \\
\hline 75. & Tail & Poti & Ikko' \\
\hline 76. & Fur & Bulu & Hulu \\
\hline 77. & Hair & $U^{\prime}$ & Belua \\
\hline 78. & Head & Ulu & Ulu \\
\hline 79. & Eye & Mata & Mata \\
\hline 80. & Nose & Ka'muru & Inge' \\
\hline 81. & Mouth & Munceng & Timu \\
\hline 82. & Car & Oto & Oto \\
\hline 83. & Tongue & Lila & Lilla \\
\hline 84. & Nail & Kanuku & Kanuku \\
\hline 85. & Feet & Bangkeng & Aje \\
\hline 86. & Knee & Kalantu' & Uttu' \\
\hline 87. & Hand & Lima & Lima \\
\hline 88. & Stomach & Battang & Perru' \\
\hline 89. & Neck & Kallong & Ellong \\
\hline 90. & Drink & Nginung & Minung \\
\hline 91. & Eat & Nganre & Manre \\
\hline 92. & Gag & Ta'lannge & Tallua \\
\hline 93. & Sugar & Golla & Golla \\
\hline 94. & Sleep & Tinro & Matinro \\
\hline 95. & Life & Tallasa' & Tuo \\
\hline 96. & Die & Mate & Mate \\
\hline 97. & Sister & Andik & Anrik \\
\hline
\end{tabular}


Laeli Qadrianti. 2(2): 193-205

\begin{tabular}{lccc}
\hline 98. & Ten & Sampulo & Seppulo \\
\hline 99. & Street & Jappa & Jokka \\
\hline
\end{tabular}

\section{a. Full Lexical Innovation}

Full lexical is a lexical innovation that has the same form between one language and another language. The full Lexical is contained in the vocabulary between the Makassar language (bM) and Bugis language (bB) as follows.

Table 2. Full lexical Innovation of Makassarese and Buginese

\begin{tabular}{lccc}
\hline No. & English & Makassarese & Buginese \\
\hline 1. & Stone & Batu & Batu \\
\hline 2. & Pencil & Potolo & Potolo \\
\hline 3. & Five & Lima & Lima \\
\hline 4. & Fruit & Bua & Bua \\
\hline 5. & Head & Ulu & Ulu \\
\hline 6. & Eye & Mata & Mata \\
\hline 7. & Car & Oto & Oto \\
\hline 8. & Sugar & Golla & Golla \\
\hline 9. & Die & Mate & Mate \\
\hline 10. & Child & Ana' & Ana' \\
\hline 11. & Line & Garisi & Garisi \\
\hline 12. & Flower & Bunga & Bunga \\
\hline 13. & Blood & Cera' & Cera' \\
\hline 14. & Horn & Tanru' & Tanru' \\
\hline 15. & Nail & Kanuku & Kanuku \\
\hline
\end{tabular}

Based on the table above, there are several words that have similarities between the Makassar language and the Bugis language. As in the word 'flower', this word has a full lexical equation. The words 'flower' are used in Indonesian (bl), Makassar language (bM), and Bugis language (bB). Based on the findings of the words, there are 15 words that have full lexical between Makassar language and Bugis language.

\section{b. Partial Lexical Innovations}

In lexical innovation, there are some forms of innovation that will be reviewed and described, namely phoneme addition, phoneme replacement, and phoneme removal. The three forms are further detailed into three parts, namely additions / replacements / omissions at the beginning of the word, the middle of the word, and the end of the word. This can be seen in the following explanation.

1) Add phonemes and / or some phonemes

Table 3. Add phonemes and / or some phonemes at the beginning of the word (prosthesis)

\begin{tabular}{lccc}
\hline No. & English & Makassarese & Buginese \\
\hline 1. & Bitter & Pai & Mapai \\
\hline 2. & Knee & Kalantu' & Uttu' \\
\hline 4. & & Tinro & Matinro \\
\hline 5. & Human & Rupatau & Tau \\
\hline 6. & Lice & Kutu & Utu \\
\hline
\end{tabular}


Based on the table above, changes can be seen at the beginning of the word. The bitter word (bl) which in Makassar (bM) ai pai 'gets the addition of two phonemes / ma / in Bugis language, namely to be' mapai '. Next, the word 'uttu' (bB) gets the addition of the phoneme / Kalan / to 'kalantu' (bM). Likewise, the word "tinro" (bM) gets the addition of the phoneme / ma / to "matinro" (bW). In human words, in Makassar the language "seems" or gets an extra lexical "appearance", while in Bugis language only "know".

Table 4. Add phonemes and / or some phonemes in the middle of the word (epentesis)

\begin{tabular}{lccc}
\hline No. & English & Makassarese & Buginese \\
\hline 1. & Where & Kemae & Kega \\
\hline 2. & Wife & Beine & Bene \\
\hline 3. & Snake & Ulara' & Ula' \\
\hline
\end{tabular}

Based on the table above, it can be seen that there are three words that experience the addition of phonemes or some phonemes in the middle of the word. In the word mana where '(bl), which in Bugis language (bB) is' gait 'gets the addition of phonemes / ma / in the middle of the word to' kemae '(bM). Furthermore, in the word wife '(bl) which in Bugis language is' bene mendapatkan get a glottal addition in the middle of the word to ane bane '(bM). As for the word 'snake' (bl) which in Bugis language is 'ula' get addition / ar / 'ulara' (bM).

Table 5. Add phonemes and / or some phonemes at the end of the word (paragog)

\begin{tabular}{lccc} 
No. & English & Makassarese & Buginese \\
\hline 1. & Leaf & Raung & Raun \\
\hline
\end{tabular}

Based on the table above, it can be seen that there is only one word that has been added at the end of the word, ie there is an addition of phoneme $/ \mathrm{g} /$ which in Bugis (bB) is 'raun' but in Makassar (bM) 'raung '.

2) Replacement of phonemes and / or several phonemes

Table 6. Phoneme replacement and/or some phonemes at the beginning of the word

\begin{tabular}{cccc}
\hline No. & English & Makassarese & Buginese \\
\hline 1. & This & Anne & Yae \\
\hline 2. & When & Sikuranna & Uppanna \\
\hline 3. & All & lyangaseng & iyaManeng \\
\hline 4. & Two & Rua & Duwa \\
\hline 5. & Four & Appa & Eppa \\
\hline 6. & Big & Lompo & Maloppo \\
\hline 7. & Water & Je'ne & Wae \\
\hline 8. & Man & Bura'ne & Urane \\
\hline 9. & Seven & Tuju & Pitu \\
\hline 10. & Clothes & Baju & Waju \\
\hline 11. & Bone & Buku & Kabuttu \\
\hline 12. & Egg & Bayao & Tello \\
\hline 13. & Fur & Bulu & Hulu \\
\hline 14. & Knee & Kalantu' & Uttu' \\
\hline
\end{tabular}




\begin{tabular}{lccc}
\hline 15. & Drink & Nginung & Minung \\
\hline 16. & Eat & Nganre & Manre \\
\hline 17. & Street & Jappa & Jokka \\
\hline 18. & Thin & Tipisi' & Manipi' \\
\hline 19. & A little & Si'di & Ce'de \\
\hline 20. & He & la & Alena \\
\hline 21. & Neck & Kallong & Ellong \\
\hline
\end{tabular}

Based on the table above, there are 21 words that experience adding phonemes at the beginning of the word. In the word "all" in Indonesian, the phoneme "iyangaseng" is obtained, while in the Bugis language "iyamaneng". In the word "bone", for the Makassar language "book", while in Bugis language get the phoneme at the beginning of the word "kabuttu".

Table 7. Replacement of phonemes and / or some phonemes in the middle of the word

\begin{tabular}{cccc}
\hline No. & English & Makassarese & Buginese \\
\hline 1. & What & Apa & Aga \\
\hline 2. & Three & Tallu & Tellu \\
\hline 3. & Sister & Andik & Anrik \\
\hline 4. & Ten & Sampulo & Seppulo \\
\hline
\end{tabular}

Based on the table above, there are several words that experience phoneme replacement in the middle of the word. The word 'What' in Indonesian experiences a phoneme / $\mathrm{g} /$ change in the word 'aga' in Bugis language. The word 'ten' in Indonesian has undergone phoneme changes to 'sampulo' in Makassar language and 'seppulo' in Bugis language. The word 'sister' in Indonesian experiences a phoneme change in the middle of the words 'andik' in the Makassar language and 'anrik' in Bugis language.

Table 8. Replacement of phonemes and / or some phonemes at the end of the word

\begin{tabular}{cccc}
\hline No. & English & Makassarese & Buginese \\
\hline 1. & You & Ikau & Iko \\
2. & Not & Teai & Tania \\
3. & Sea & Tamparang & Tasi \\
4. & One & Se're & Se'di \\
5. & Father & Angge' & Ambo' \\
6. & Bag & Tasi & Tase \\
7. & Spoon & Sondok & Sinru \\
8. & Gag & Ta'lannge & Tallua \\
9. & Life & Tallasa' & Tuo \\
10. & Street & Jappa & Jokka \\
\hline
\end{tabular}

Based on the table above, some words that experience phoneme replacement at the end of the word. The word 'you' in Indonesian experiences the phoneme replacement to be 'ikau' in Makassar language and 'iko' in Bugis language.

b) No cognate

The latest innovation or symptom in this writing is non-cognitive vocabulary. This means that the Makassar language vocabulary (bM) described above is very 
different or not the same as the Bugis language vocabulary (bB). The vocabulary included in the symptoms of non-cognition can be seen in the following table.

Table 9. The non-cognitive vocabularies between Makassarese and Buginese

\begin{tabular}{|c|c|c|c|}
\hline No. & English & Makassarese & Buginese \\
\hline 1. & 1 & Nakke & lya' \\
\hline 2. & We/Us & Katte & Idi' \\
\hline 3. & White & Kebo & Mapute \\
\hline 4. & That & Antu & Yaro \\
\hline 5. & Who & Inai & Niga \\
\hline 6. & Chicken & Jangang & Manu \\
\hline 7. & Many & Loe & Mega \\
\hline 8. & Long & La'bu & Malampe \\
\hline 9. & Baring & Monrang & Leu \\
\hline 10. & Narrow & Seppang & Macipi' \\
\hline 11. & Women & Baine & Makkunrai \\
\hline 12. & Husband & Bura'neng & Lakkai \\
\hline 13. & Mother & Ammak & Indo \\
\hline 14. & Fish & Juku & Bale \\
\hline 15. & Bird & Jangang-jangang & Dongi' \\
\hline 16. & Forest & Romang & Ale' \\
\hline 17. & Meat & Dageng & Juku' \\
\hline 18. & Nose & Ka'muru & Inge' \\
\hline 19. & Mouth & Munceng & Timu \\
\hline 20. & Feet & Bangkeng & Aje \\
\hline 21. & Thick & Kapala' & Maumpe' \\
\hline 22. & Weight & Battala' & Matane \\
\hline 23. & Root & Aka' & Ure \\
\hline 24. & Skin & Bukkuleng & Uli' \\
\hline 25. & Rope & Passikko & Tulu' \\
\hline 26. & Fat & Janna & Lappe \\
\hline 27. & Hair & U' & Belua \\
\hline 28. & Tail & Poti & Ikko' \\
\hline 29. & Stomach & Battang & Buba \\
\hline
\end{tabular}

Based on the table above, there are 29 Indonesian words that are not cognate with words contained in the Makassar language and Bugis language. The word 'mother' in Indonesian does not have an equation with the Makassar language 'ammak' in Bugis' 'Indo'. Besides that, in the word 'belly' in Indonesian, it does not have an equation with the Makassar language 'battang' in Bugis' 'buba' language.

\section{Conclusion}

Language variations are always interesting to study. This is because the study can describe and provide a description of language users about innovations found in a language. Similarly, the Makassar language (bM) and Bugis language (bB) have been described previously. Both languages are both languages in South Sulawesi but are full of diversity of languages and dialects. 


\section{References}

Chaer, A. \& L. Agustina. (2004) Sosiolinguistik Perkenalan Awal. Jakarta: Rineka Cipta,.

Kridalaksana, H. (1983). Kamus Linguistik. Jakarta: P.T. Gramedia.

Mulatsih, D. (2016). Inovasi Bentuk dalam Bahasa Sunda Di Kampung Puyuh Koneng, Desa Kencana Harapan, Kecamatan Lebak wangi, Kabupaten Serang, Provinsi Banten, Jurnal Logika, Vol. XVII, Nomor 2, (Universitas Swadaya Gunung Jati), h. 7.

Moleong, L. J. (2009). Metodologi Penelitian Kualitatif. Ed. Revisi. Bandung: Remaja Rosdakarya.

Mutmainnah, E. (2018). Munirah. Penggunaan Bahasa Indonesia Dialek Makassar Dalam Kegiatan Pembelajaran di SMA NEGERI 6 Maros: Kajian Sosiolinguistik, Jurnal IImu Budaya, Vol. 6 Nomor 2.)

Ramli, A., et al. (nd). Ragam Bahasa Masyarakat Belopa Kabupaten Luwu dan Relevansinya dalam Pembelajaran Sosiolinguistik di Universitas Cokroaminoto Palopo (Tinjauan Sosiolinguistik), Makalah.

Wahya. (2010). Inovasi Bentuk Dalam Variasi Geografis Bahasa Sunda: Kedinamisan Dan Keharmonisan Dalam Perubahan Bahasa lbu disajikan pada Seminar Internasional Hari Bahasa lbu pada tanggal 19-20 Februari 2010 di Bandung.

Wahya. (2005). Inovasi dan Difusi Geografis Leksikal Bahasa Melayu dan Bahasa Sunda di Perbatasan Bogor-Bekasi: Kajian Geolinguistik. Disertasi. Bandung: Program Pascasarjana Universitas Padjadjaran.

Waridah. (2005). Penggunaan Bahasa dan Variasi Bahasa dalam Berbahasadan Berbudaya, Jurnal Simbolika Vol. 1, No. 1, Universitas Medan Area. 